\title{
WestVirginiaUniversity
}

THE RESEARCH REPOSITORY @ WVU

Graduate Theses, Dissertations, and Problem Reports

2006

\section{The Reggio Emilia approach to education and its relationship to art education}

Debra N. Hart

West Virginia University

Follow this and additional works at: https://researchrepository.wvu.edu/etd

\section{Recommended Citation}

Hart, Debra N., "The Reggio Emilia approach to education and its relationship to art education" (2006). Graduate Theses, Dissertations, and Problem Reports. 3231.

https://researchrepository.wvu.edu/etd/3231

This Thesis is protected by copyright and/or related rights. It has been brought to you by the The Research Repository @ WVU with permission from the rights-holder(s). You are free to use this Thesis in any way that is permitted by the copyright and related rights legislation that applies to your use. For other uses you must obtain permission from the rights-holder(s) directly, unless additional rights are indicated by a Creative Commons license in the record and/ or on the work itself. This Thesis has been accepted for inclusion in WVU Graduate Theses, Dissertations, and Problem Reports collection by an authorized administrator of The Research Repository @ WVU. For more information, please contact researchrepository@mail.wvu.edu. 
The Reggio Emilia Approach to Education and Its Relationship to Art Education

Debra N. Hart

Project Report submitted to the College of Creative Arts at West Virginia University In partial fulfillment of the requirements

For the degree of

Master of Arts

In

Art Education

Dr. William J. Thomas, Chair

Dr. Victoria Fergus

Professor Kristina Olson

Division of Art

Morgantown, West Virginia

2006

Keywords: Art, Art Education, Reggio Emilia Approach

Copyright 2006 Debra N. Hart 


\begin{abstract}
The Reggio Emilia Approach to Education and Its Relationship to Art Education
\end{abstract}

Debra N. Hart

This project deals with the concept of the Reggio Emilia approach to education. This open-ended, child-centered method of teaching is coming into light as a methodology used to educate children in a positive and nurturing manner. From its basic philosophy and its guiding principles, the Reggio Emilia approach to education has a strong foundation. Its background, historical context, and existing literature on educational psychology support the use of this method. Current practices in art education and national and state standards make it difficult to envision the implementation of the Reggio Emilia approach to education, since it would require a dramatic shift from a subject-centered to a child-centered curriculum. 


\section{ACKNOWLEDGEMENTS}

I wish to thank many people in my life who have guided me through this learning process that has become a labor of love for me. Firstly, thank you to my family who has been there for me through thick and thin. A special thank you to my mother whom I wish could have been here to witness this event. Her inspiration as a third grade teacher has profoundly influenced my goal to become a teacher and to make a difference in the lives of my students.

Secondly, thank you to my friends who, too, have endured the strenuous efforts of my stages in this master's thesis. To those who have gone before me and to those who will follow in my footsteps, I thank you all.

Thirdly, I wish to exuberantly thank my advisor and professor, Dr. William J. Thomas for providing the encouragement and the motivation to develop this thesis based on a simple article on Reggio Emilia that existed in his files, just waiting for me to get a hold of this concept. Dr. Thomas is a very special person, with a gift for teaching students of all levels.

Additionally I wish to thank all of my thesis committee: Dr. Victoria Fergus and Professor Kristina Olson for their unending support and all that they have taught me through these years. They have shown me that no matter how much knowledge one obtains, there is always so much more to learn. I wish to extend this thanks to Dr. Joy Saab, for showing us Reggio Emilia itself and the true wonders of the "real thing". 


\section{TABLE OF CONTENTS}

Acknowledgements.............................................................................. ii

Introduction: The Basic Philosophy of the Reggio Emilia Approach .....................1

Guiding Principles of Reggio Emilia ...................................................... 1-6

Background of Reggio Emilia: Historical Context and

Existing Literature ....................................................................................... 6-16

The Relationship Between Reggio Emilia and Current Points of View in Art Education $17-24$

The Relationship Between Published Art Education Standards and Reggio Emilia: National and State (NAEA) Standards ........................................... 25-32

Chapman and Hubbard ................................................................ 32-39

Can Art Education Be Taught in a "Reggio Emilia” Way in the U.S. Public Schools? 39-42

Implications for Art Education ........................................................ 42-43

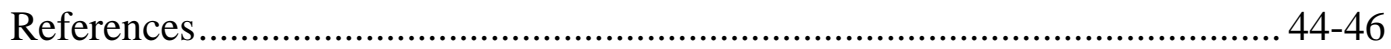




\section{Basic Philosophy of the Reggio Emilia Approach to Education}

"A work of art expresses a conception of life, emotion, inward reality. But it is neither a confessional nor a frozen tantrum; it is a developed metaphor, a non-discursive symbol that articulates what is verbally ineffable- the logic of the consciousness itself."1

-Suzanne Langer

Within this quote by Susanne Langer, a twentieth century philosopher who describes what art is, there is a metaphor that helps us to understand the Reggio Emilia approach to learning. In teaching art to his or her students, a competent teacher will allow the creative spirit to thrive within each student and encourage the student's selfexpressiveness. The Reggio Emilia approach is based on this kind of thinking. Although it is not specifically used to teach only art, it is a philosophy of teaching that believes in the children's abilities, in hope, and in the possibilities that can occur in learning because of an open-mindedness regarding the human being.

\section{Guiding Principles}

The Reggio Emilia approach to education is one that consists of two major principles which are deeply interrelated. The first major principle deals with the nature of the child. The Reggio Emilia philosophy believes in a very particular and positive image of the young child. These educators believe that the young child comes to the classroom both knowledgeable and competent. They believe that the child has something significant to contribute to their educational process and that they have inherent knowledge that they

\footnotetext{
${ }^{1}$ Suzanne Langer. Problems of Art: Ten Philosophical Lectures (New York, N.Y.: Charles Scribner and Sons, 1957), 23.
} 
bring to the classroom to share. At the turn of the century, the German philosopher, Friedrich Wilhelm August Froebel (1782-1852), presented the concept of the educational significance of children's play. It was Froebel who was the first to develop a school on the theory of a garden of children, and coined the name Kindergarten, comparing the educational growth of a child to the growth of a plant. Prior to Froebel, Jean Jacques Rousseau (1712-1778) was the first to popularize the aspect of romantic naturalism in educational philosophy, emphasizing the voluntary impulses of children. Rousseau believed that nature must have free play, and it must be uninhibited.

The nature of the learning process is the second major principle and is dictated by Reggio Emilia's ideas about the nature of the child. The learning process is collaborative and discovery-based and, as such, it takes the form of long-term projects designed in an open-ended manner. This allows students complete exploration of their world and learning environment. The Reggio Emilia concept that "creativity takes time...” is employed by long, unstructured blocks of time for research and creativity to take place. The teachers of Reggio Emilia encourage the natural ability of the child to come out. Although the teachers play an active role in collaborating with the students, they also let the students work in a free-thinking mode, allowing for ideas of the students to take precedence in the formation of a project's concept. The project takes shape in consultation with students, teachers, and members of the community.

In addition, the nature of the learning process is further defined by the following. First, Reggio Emilia educators believe that the role of the learning environment is to teach the students. The environment is everything and should be designed as such. For example, because they believe that the child can handle glass, dining tables are set with 
real tablecloths and cloth napkins, authentic silverware, and glasses made out of glass. Centerpieces are made of live plants. They are truly trying to make the school like the home, which is basically a community-based educational philosophy. This facilitates a smooth and more comfortable transition from the home to the school environment. It is natural for the home and school to be connected. This also provides a very stable and unfractured environment for the child. There is a great importance placed on the home and the school relationship. Additionally, this truly shows the respect that the educators have for the children, and how they highly value and care to protect the child and his or her environment. These central features of the learning process are designed to foster deep understanding, which is the purpose of the project and this learning process.

In addition, collaboration and documentation are considered crucial in the Reggio Emilia methodology. Within the concept of social constructivist theory, Reggio Emilia educators value the contributions of children in the development of their own knowledge, and they believe that knowledge is constructed with others. This is defined as collaboration. Likewise, the community is valued as an integral part of the students' dayto-day education. Parents are encouraged to attend the school as well. They are invited to join in the projects and activities and are asked to participate and share their own areas of expertise and experience with the students. Parent participation seems to be a trend in current educational practice, yet Reggio Emilia educators have been working in this manner for $50+$ years. Collaboration takes place at the beginning of a project through its completion.

Like collaboration, documentation is an integral part of the educational experience. It is the primary way of capturing the "life" of a project. Documentation 
includes a foundation in observation, dialogue, communication, and joint problem solving at all levels of this system. The Reggio Emilia students are observed and recorded in many different ways. Slides are used to chart the progress of long-term projects, video is recorded, and audiotape is used to document the questions asked by the students and the resulting answers. Conversations between the students themselves and between students and teachers are very important. Educational enrichment is gained through the student's learning experience, as observed by what the students see, notice, say, and examine for them. Teachers use documentation not only to record the history of a project, but even more importantly, to guide learning and educational practice. Children contribute to and discuss this documentation. It is a way of representing what the students are learning.

Deep understanding within the Reggio Emilia system is realized through the combination of the aforementioned elements. The concept of deep understanding considers the student receiving an in-depth look at an idea by exploring things from many different points of view. The Reggio Emilia approach believes in students exploring the sensory and tactile experience of an object, by discovering things in a physical way. The Reggio Emilia educators believe in the fact that things change over time and that this is a concept a child should learn from a very young age. These educators guide the children to explore the details of the things they examine, by allowing them to play, touch and thoroughly immerse themselves in their experience. They trust that ideas should be celebrated, and so should the children who create these ideas. The Reggio Emilia approach allows preschool children to express and communicate their ideas, understandings, imaginings, observations, and feelings through visual representations. 
This serves as a basis for modifying, developing, and deepening understanding, which leads to further observations and fresh representations by the students. By using this approach, children's minds can be engaged in a multitude of ways in the quest for deeper understanding of the familiar world around them. ${ }^{2}$

Another important concept is the unity of thinking and feeling. This principle deals with the Reggio Emilia methodology, or how this approach actually works. To combine the concept of thinking and feeling, Reggio Emilia educators consider concepts such as exploration, representation, and communication to be paramount. The first concept, exploration, involves bringing to life the environment the children reside in, which is a key issue for Reggio Emilia educators. Within the concept of exploration, there is the notion of questioning and adaptation, referring to using an everyday experience to enhance a child's view of the world. This reflects a "project-centered" approach, whereby children learn by doing, and exploring elements within their own life. Additionally, with the idea of reflection the children are considering something carefully and examining all of the aspects of this idea. This relates to looking at things from many different points of view.

The second concept is representation, the way in which children record and embody their memories, ideas, predictions, hypotheses, observations, and feelings. This typically visual concept allows us to explore the aesthetic concerns of the student and the teacher. This is inherent in the Reggio Emilia teaching philosophy. A non-visual part of the learning process refers to research, otherwise known as the beginning progression of a long-term project. This speaks of the processes of observation and brainstorming. The

\footnotetext{
${ }^{2}$ Carolyn Edwards, Lella Gandini, and George Forman, The Hundred Languages of Children: The Reggio Emilia Approach - Advanced Reflections (Westport, C.T.: 1998), 371.
} 
development of research is important for the child's growth and knowledge ability. It is in this initial stage that learning truly begins to take place. It is also here that a child's potential is born. As mentioned above, documentation is an important way in which the children represent what they are learning.

The last concept Reggio Emilia educators consider, communication, refers to a student's ability to express his or her own thoughts and ideas. The Italian saying: Io chi Siamo translates to "I am who we are". This means that the individual is honored as much as the group. This is a strong statement about the kind of cooperation and collaboration that must take place in a unique environment such as the Reggio Emilia schools.

In summary, the Reggio Emilia approach encompasses the nature of the child as well as the nature of the learning process. The role of the environment, as well as collaboration and documentation, are also crucial. Concepts such as exploration, representation, and communication are paramount. The next section of this paper will discuss past philosophers whose concepts of education and instruction provide a foundation for the Reggio Emilia approach.

\section{Background of Reggio Emilia: Historical Context and Existing Literature}

To better understand Reggio Emilia philosophy, it is crucial to look back at past philosophers whose concepts of education and instruction provide a foundation for the Reggio Emilia approach. Following this philosophical background information, the history of Reggio Emilia itself and its origins will be explained. 
There have been many different developmental theoretical views of the child, which have helped to organize and guide our thinking, study of children, and our teaching practices. ${ }^{3}$ Current practices in educational psychology and developmental psychology are observing changes in the world we live in and how this affects the world in which we teach. Understanding the image or interpretation of the child is crucial to understanding how to educate this incredibly absorbent human being. Herein lays the crux of the Reggio Emilia approach. By looking at some of the past developmental theorists to gain insight into the world of Reggio Emilia, particularly those who believed in romantic idealism, we begin to become familiar with some of the principles of learning to which the Reggio Emilia approach subscribes.

Jean Jacques Rousseau (1712-1778) was an eighteenth century romanticist. Romanticism was the naturalistic philosophy of education. It strongly influenced the teaching philosophy of the nineteenth and twentieth centuries. Romanticism posed that in addition to reason, man has feelings, which are just as much a part of nature as reason. Rousseau believed in instruction through the senses. Rousseau's primary conviction was that "true education consisted less in knowing than in doing." ${ }^{4}$ He believed in a sense of feeling and that the central feature of the teacher's strategy should be to maneuver the pupil into wanting to learn. "Give the child the wish and... any method will then be suitable." ${ }^{5}$ Rousseau's concept was that the inner drive that would carry the child furthest along in his or her studies would be present interest. This, along with inclination, was so important to Rousseau, that he depended upon them to teach a child sustained attention

\footnotetext{
${ }^{3}$ Victoria R. Fu, Andrew J. Stremmel, and Lynn T. Hill, Teaching and Learning, Collaborative Exploration of the Reggio Emilia Approach (Upper Saddle River, N.J.: Merrill Prentice Hall, 2002), 92.

${ }^{4}$ John S. Brubacher, A History of the Problems of Education (New York, N.Y.: McGraw-Hill Book Company, 1966), 204.

${ }^{5}$ Ibid.
} 
and perseverance in the face of difficulty and distractions. A child must be actively engaged in experience rather than being in a receptive position, thus being provided experiences. It was Rousseau's conviction that children are naturally predisposed to learning, and that the teacher/educator needs to set the conditions to bring this learning about. This statement parallels the Reggio Emilia approach to education. In Rousseau's publication Emile, from 1911, he popularized the aspect of naturalism in educational philosophy. Rousseau emphasized the voluntary impulses of children. He professed that the three main influences on education are: nature, man, and things. Men and things can be consciously controlled, while nature is an independent "datum” or given. Therefore, nature is the controlling consideration to which the other two influences must be subordinate for a complete education. "Nature must have free play, it must be uninhibited." ${ }^{6}$ Rousseau's vision of the learning child is one of respect, inherent capability, and he believed that the student is naturally intelligent. His doctrine of interest made pupil freedom an essential part of the teacher's method. This freedom included dressing children in loose fitting garments "inviting the quick and easy uncoiling of native springs of energy to an approval of the child's pursuit of his own inclinations."

Rousseau alleged that if a child were restless, they should treat this manifestation of energy as a necessary apprenticeship in learning. An important basis for giving the child freedom was inherent in the concept of believing that each child is born with their own distinctive temperament. A serious fault he found with the methods of his day was that all children were indiscriminately set up with the same exercises, thus destroying any special "bent” they may possess and leaving a "dull uniformity." In a 1912 publication by

\footnotetext{
${ }^{6}$ John S. Brubacher, A History of the Problems of Education (New York, N.Y.: McGraw-Hill Book Company), 1966, 206.

${ }^{7}$ Ibid.
} 
R. L. Archer entitled Rousseau on Education, Rousseau says that liberty gives children not more but less right to command others. Freedom requires children to learn by depending more heavily on their own resources. By doing this, they will learn to limit their desires to their capacities to fulfill them. Rousseau's plea was to "hold childhood in reverence" and to "give nature time to work....” This romantic regard for the subtle forces of nature finding expression during the period of childhood is extensibly the theory of Rousseau. It was Rousseau who proposed that learning institutions "be made consistent with giving free play to the native instincts and impulses of the individual” ${ }^{9}$ and that the aim of education was to develop free, spontaneous expression.

Friedrich Wilhelm August Froebel (1782-1852) was a German educational philosopher. Froebel's publication The Education of Man dealt with romantic idealism. Romanticism emphasized the notion of feeling, as did much of the findings of Rousseau. There became much more of an emphasis on emotion and will. His educational aims were oriented to the child's interests and capacities. Froebel was the first to perceive and discuss the educational significance of children’s play. It was his belief that “The child does not possess activity, he is activity." It was also Froebel’s philosophy that "play" was the natural mode or outlet for the expression of self-activity, developing in each individual the divine unity within themselves. ${ }^{10}$ Froebel perceived that "play is in itself educational. ${ }^{11}$ Froebel was the first to organize a school on the theory that it was a garden of children, a Kindergarten, wherein the educational growth of children could be compared to the growth of plants. In other words, Froebel believed that children needed

\footnotetext{
${ }^{8}$ John S. Brubacher, A History of the Problems of Education (New York, N.Y.: McGraw-Hill Book Company, 1966), 206.

${ }^{9}$ Ibid, 126.

${ }^{10}$ Ibid.

${ }^{11}$ Ibid.
} 
to be nurtured, not shaped. This "unfoldment”"12 philosophy bears resemblance to Aristotle's developmental theory of education whereby development is teleological (purposeful); the final end, or product, is foreshadowed in the germ. Interestingly, Froebel was one of the first to denote his appreciation of the significance of the mother as the earliest teacher of childhood. He perceived that the whole educational edifice rests on the foundation of home training, and towards his death he called upon the state to establish institutions not only for the education of children but also for the education of parents and those who were to become parents. This parental involvement is fundamental to the concept of the Reggio Emilia approach. Froebel, like Rousseau, aimed at developing the inner nature of the child. Froebel felt that this inner nature was self-active. He believed that the proper aim of education was to afford opportunity for the selfexpression of this inner principle of activity. Froebel's goal was to raise free-thinking, and independent people. Froebel theoretically sustained the philosophical romantic interests of Rousseau, by way of the spontaneous impulses of the child ultimately finding outlet in the fine arts. By developing a child's internal senses through an exercise such as painting, extensive practical support for a curriculum of fine arts was derived. Froebel tried for greater spontaneity in education and curriculum instruction, observing, “...art alone can truly be called free activity....”13 Froebel was also the first educational philosopher to propose the use of social tactics in the classroom, that were based on a particular strategy. For instance, the enduring kindergarten circle was representative of the all-inclusive unity. Proposed to permit growth from the children's entering into social relationships with their peers, the formal arrangement of early learners into a circle would

\footnotetext{
${ }^{12}$ John S. Brubacher, A History of the Problems of Education (New York, N.Y.: McGraw-Hill Book Company, 1966), 16.

${ }^{13}$ Ibid., 126.
} 
also stimulate the development encountered from the very early intimacy between mother and child (otherwise known as "circle time" today). Additionally, the social environment of the school was to teach the child that he was both a whole and a part within a whole. Unfortunately, it wasn't until after Froebel's passing that his American followers undertook implementing his developments, even at the higher levels of learning. Both Rousseau and Froebel form a background that emphasizes setting the conditions that foster discovery learning, along with a great respect for the natural development of the child. This is an essential part of teaching and learning, analogous to the Reggio Emilia approach.

At the turn of the century, John Dewey (1859-1952) was especially influential in developing teaching strategies to promote creative behaviors in children. ${ }^{14}$ Dewey was one of America's leading educational innovators, surfacing from an experimental school at the University of Chicago. It was there that he instituted a curriculum that gave a central position to activities such as cooking, sewing, and carpentering, activities with which the child was already familiar within the community. When subject matter was taught, it was done so in conjunction with these activities rather than in the conventional fashion. Subsequently following this method, the University of Missouri abandoned traditional subject matter in favor of a fourfold curriculum of observation, play, stories, and handwork. In Rousseau's words, “...they were cutting the cloth to fit the child.” 15 Both Rousseau and Froebel form a background that emphasizes setting the conditions

\footnotetext{
${ }^{14}$ Jane K. Bates, Becoming an Art Teacher (Belmont, C.A.: Wadsworth/Thompson Learning, 2000), 14.

${ }^{15}$ John S. Brubacher, A History of the Problems of Education (New York, N.Y.: McGraw-Hill Book Company, 1966), 204.
} 
that foster discovery learning. This is an essential part of teaching, along with a respect for the natural development of the child.

"In teaching, our ability to reason is connected to our imagination...reason must fall back upon imagination-upon the embodiment of ideas in an emotionally charged sense.” 16

\section{-John Dewey}

Dewey recognized the role of imagination in bringing life into the act of teaching and learning. ${ }^{17}$ The form that this took was sympathetic to the ideas of Froebel and Rousseau concerning the natural capabilities of the child and the need to construct the conditions within which discovery learning could take place. Dewey believed that the social process is all one with the educational process. He believed that the educational measure of a good society is the extent to which its individual members share or communicate cultural resources among its various members. In 1916, John Dewey published a ground-breaking volume entitled Democracy and Education. According to Brubacher in A History of the Problems of Education, this was the most important treatise on education and political or social theory since Plato’s Republic. This text incorporated his new philosophy, entitled “progressive education.” Dewey’s concept that "school is not preparation for life - it is life" ${ }^{18}$ (congruent with what Froebel would say: the child is activity) invites us to visualize that each person must create his or her own personal meaning; using all of the tools available, including reading, writing, speaking, listening, drama, music, art, literature, and dance. Dewey strongly believed in the

\footnotetext{
${ }^{16}$ John S. Brubacher, A History of the Problems of Education (New York, N.Y.: McGraw-Hill Book Company, 1966), 48.

${ }^{17}$ Victoria R. Fu, Andrew J. Stremmel, and Lynn T. Hill, Teaching and Learning, Collaborative Exploration of the Reggio Emilia Approach (Upper Saddle River, N.J.: Merrill Prentice Hall, 2002), 128.

${ }^{18}$ Claudia E. Cornett, Creating Meaning Through Literature and the Arts: An Integration Resource for Classroom Teachers (Upper Saddle River, N.J.: Merrill Prentice Hall, 2003), 32.
} 
"problem method" or rather the problem-solving technique. It was Dewey who brought on the creation of study questions and guides, suggested field trips, experiments, and child-centered activities to promote the best possible learning environment. He stressed that students should be engaged in problem solving related to life experiences rather than a fixed body of information to be transmitted to them. This child-centered orientation introduced by Dewey, and practiced in the Progressive Movement, finds its legacy in both the teachings of Froebel and Rousseau. Additionally, this concept becomes the thread upon which the Reggio Emilia approach has been constructed.

Lev Vygotsky (1896-1934) challenged the notion that the child constructs a knowledge of reality solely on the basis of private encounters with the world by proposing alternatively that the child's encounters are mediated through negotiation with others who have more skill or competence in given situations. The concept of children learning with others demonstrates the notion of collaboration and documentation. ${ }^{19}$ In 1926, his publication Educational Psychology was written as a practical manual for teachers during his residency at the Institute of Psychology at Moscow University, before beginning the experimental work that led to the formulation of his celebrated ideas on human development. Vygotsky believed that children gain significantly from the knowledge and conceptual tools handed down to them by those who are more intellectually advanced, be it peers, older children, or adults. He had strong views about the role of social interaction and formal instruction. Vygotsky believed that collaboration promotes cognitive growth because of the way in which

\footnotetext{
${ }^{19}$ Jack Snowman and Robert Biehler, Psychology Applied to Teaching (Boston, MA: Houghton Mifflin Company, 2000), 57.
} 
students model for each other more advanced ways of thinking than any would demonstrate on an individual basis.

"Whenever children are not trying to guess what sort of response their teacher is expecting, but speak sincerely and on their own, their judgments are so at variance with the moral the teacher may be hoping to impart that some educators have come to think that even indisputably “ethical” works may turn out to exert a morally harmful influence when they are passed through the prism of a child's mind.”20

-Lev Vygotsky

Vygotsky was interested in the role of children's play, analogous to Froebel’s theory. In his text entitled Play and its role in the Mental Development of the Child, published in 1933, he states “In speaking of play and its role in the preschooler's development, we are concerned with two fundamental questions: first, how play itself arises in development - its origin and genesis; second, the role of this developmental activity, which we call play, as a form of development in the child of preschool age.”21 Vygotsky continues by saying “Without a consideration of the child's needs, inclinations, incentives, and motives to act - as research has demonstrated - there will never be any advance from one stage to the next.”22

"Imagination is a new formation that is not present in the consciousness of the very young child, is totally absent in animals, and represents a specifically human form of conscious activity. Like all functions of consciousness, it originally arises from action. This is a direct reference to the philosophy of Froebel, yet a different way of expressing

\footnotetext{
${ }^{20}$ Lev Vygotsky Archive, http://www.marxists.org/archive/vygotsky/works/1926/educational-psychology/ch13.htm, September 2004.

${ }^{21}$ Ibid.

${ }^{22}$ Ibid.
} 
his educational theory. The old adage that children's play is imagination in action can be reversed: we can say that imagination in adolescents and school children is play without action., ${ }^{23}$ Vygotsky emphasized the role of teachers, parents, siblings, and other kinds of expert tutors in meaningful learning. This is the crux of the Reggio Emilia philosophy. Vygotsky divided learning into several categories. "Direct learning” is defined as unfiltered contact with stimuli, whereas "mediated learning” is when a more knowledgeable and skilled individual selects stimuli to attend to, directs attention to certain aspects of the chosen stimulus, and explains why things are the way they are and why things are done in a certain way. Therefore, the Vygotskian perspectives' main goal is to provide learners with the psychological tools they will need to engage in selfmediation. This process is referred to as "transfer of learning" by psychologists, and allows the student to look beyond the immediate situation to use new knowledge and skills in future situations. Vygotsky believed that by actively engaging with others who have more competence or skill in a situation, more progressive learning would occur. This concept holds that the "spirit of collaborative dialog combines the ideas of humanistic perspectives with a belief in a socially constructed world where a child's or a teacher's potential, capacity, and creativity are realized through a continually evolving system of social interactions." 24

The Reggio Emilia approach clearly has its legacy in educational philosophy from past theorists. As has been discussed, there have been numerous educational philosophers and educational psychologists throughout history, each with his or her own viewpoints of

\footnotetext{
${ }^{23}$ Lev Vygotsky Archives, http://www.marxists.org/archive/vygotsky/works/1926/educational-psychology/ch13.htm, September 2004

${ }^{24}$ Victoria R. Fu, Andrew J. Stremmel, and Lynn T. Hill, Teaching and Learning, Collaborative Exploration of the Reggio Emilia Approach (Upper Saddle River, N.J.: Merrill Prentice Hall, 2002), 203.
} 
educational foundations of learning. By examining Rousseau, Froebel, Dewey, and Vygotsky we become familiar with the principles of learning that begin to hint at the make up of the Reggio Emilia approach to education. Additionally, the visions of the teachers, parents, and children of Reggio Emilia and particularly its founder, Loris Malaguzzi, have come together to create this dynamic approach to learning. Reggio Emilia is truly a journey of learning. What exemplifies Reggio Emilia from most other methods of teaching is that Reggio encourages us to reconsider the meaning of teaching and to rediscover the art of teaching. ${ }^{25}$

In summary then, a major distinction of the Reggio Emilia approach is that of allowing the child to be the collaborator and communicator and believing in the child's knowledge-abilities and capabilities. It is also Reggio Emilia’s conviction to believe in a respect for nature and the natural development of an idea as well as the child's natural development concurrent with the education of that child. The concept and importance of free play in addition to using documentation as a form of communication are all part of the Reggio Emilia approach. Additionally, permitting the environment to serve as the third teacher, seeing the teacher as partner, researcher, nurturer and guide, inviting the parents and community members to participate as teachers - all come together as vibrant conditions to be designed for life-related projects and problem solving, culminating in a substantially successful learning environment.

\footnotetext{
${ }^{25}$ Victoria R. Fu, Andrew J. Stremmel, and Lynn T. Hill, Teaching and Learning, Collaborative Exploration of the Reggio Emilia Approach (Upper Saddle River, N.J.: Merrill Prentice Hall), 2002.
} 


\section{The Relationship Between Reggio Emilia and Current Points of View in Art Education}

Now, it is important to consider current practices in art education in order to get an overview or general sense of ideas and policies governing art education at the Kindergarten to fifth grade levels.

Elliot Eisner is an art educator at Stanford University, who has devoted most of his professional life to advancing the cause of art education in the United States. Dr. Eisner is an educational theorist and critic, rather than a psychologist. Eisner has served as president of the National Art Education Association, the International Society for Education through Art, the American Research Association, and is currently presidentelect of the John Dewey Society. A writer and curriculum designer, Eisner is a current supporter of DBAE, or Discipline Based Art Education. As formalized in the 1980s, a subject-centered, content-centered approach came about beginning in the 1960s with a major movement in content and structure. According to Eisner general education became harshly academic, a "back to basics" approach, and art education that focused on freedom of self-expression was perceived as "soft” and lacking substance. Therefore, the childcentered approaches and experiential studio activities shifted to curricula with concrete, specific concepts and content to parallel the educational processes in math and science areas. ${ }^{26}$ Teaching the arts as a discipline-based approach with specific components became a vehicle to elevate the status of the arts to the level of other curriculum areas. Defined specifically, Discipline-Based Art Education is seen as four interrelated domains or disciplines:

\footnotetext{
${ }^{26}$ Stephen Mark Dobbs, Research Readings for Discipline-Based Art Education: A Journey Beyond Creating (Reston, V.A.: National Art Education Association), 1988.
} 
- Art Production-focusing on art making

- Art Criticism-focusing on perceiving and understanding visual qualities of art through the use of critical dialog.

- Aesthetics-focusing on the development of appreciation, personal taste, and knowledge of art's value as established within various times, places, and cultures.

- Art History-focusing on art within the context of history and culture.

This definition came out of The Getty Center for Education in the Arts goal to balance art making with the study of art in culture and art as culture. The institute provided research, curriculum, and training to implement its philosophy and to fulfill the primary goal of the National Art Education Association (NAEA) which was: “All elementary and secondary schools shall require students to complete a sequential program of art instruction that integrates the study of art production, aesthetics, art criticism, and art history."27

In Eisner's publication The Role of Discipline-Based Art Education in America's

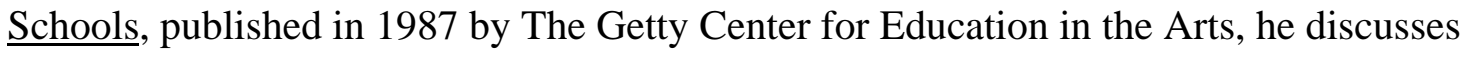
why education in the arts is so vital. Eisner explains his theory of the development of multiple forms of literacy, or the skills young people need to acquire to tap into their cultural resources. He states that through the visual arts we can share aspects of our experiences. The arts that constitute one of the important forms of representation through which humans share what they have thought, felt or believed. We can also share our thoughts through forms of representation such as dance, poetry, drama, etc. The human need to express what they experience has allowed our culture to create so many different

\footnotetext{
${ }^{27}$ Jane K. Bates, Becoming an Art Teacher (Belmont, C.A.: Wadsworth/Thompson Learning, 2000), 87.
} 
forms of literacy. Eisner believes that it is the school curricula in which our children will learn the languages of these forms, consequently gaining access to the kinds of experience that the forms make possible. The children's level of development depends on the kinds of opportunities they are offered for acquiring these skills, which should occur in their educational environment. Learning the languages of art presupposes an existing set of skills that compose the language or in this case the subject matter.

There are fundamental differences in the D.B.A.E. philosophy and the Reggio Emilia approach. This particular subject-centered approach does not dovetail tightly with the Reggio Emilia concerns. This shift from child-centered to subject-centered methods of teachings in art education moves the discussion further from the true philosophy of Reggio Emilia. Essentially, Eisner's point of view places him in a mild but never the less subject-centered curriculum.

Howard Gardner is a psychologist and professor at Harvard University, most noted for his work in multiple intelligences. Gardner's theory of “multiple intelligences” deals with conceptualizing the arts as expanding ways of knowing and expressing. Four of his eight intelligences are arts based: musical, visual (art), body-kinesthetic (drama/dance), and verbal (literature). The other four are all arts connected (logical, interpersonal, intrapersonal, and naturalistic). In Gardner’s 1993 publication Creating Minds, he expresses how math and science can be taught through using musical intelligence, by kinesthetic means (dance/drama), or through the visual arts, giving the students more means to enjoy learning and more reasons to return to art in the future. He believes that teachers need to teach to interests, and develop new interests by presenting 
subject matters in new, unique, and most importantly; exciting ways. This belief is strongly held by all Reggio Emilia teachers. ${ }^{28}$

Gardner further explored the power of group learning and documentation. “Our hypothesis was that documentation not only allows us to make visible the dynamics of individual and group learning, but also is itself a tool that can promote individual learning within the group as well as learning by the group as a whole.”29

In an article published by the Harvard University Gazette, researchers from “Project Zero”, a research project at the Harvard University Graduate School of Education studied how children learn in a partnership with Reggio Emilia schools. Gardner published a book from his research entitled Making Learning Visible: Children as Individual and Group Learners. He stresses that preschoolers have an incredible potential to focus, to concentrate, to spend weeks, even months on a topic. Much like Vygotsky’s group learning and collaboration and project-orientated activities are essential to the students' development, the development is both fostered and manifested by what he calls “multiple intelligences.” This relates very closely to Reggio Emilia.

Yet another contemporary theorist Jerome S. Bruner in his text The Course of Cognitive Growth, articulates the Froebel concept of the child developing from the inside out although he also believes that the child develops from the outside in as well. This kind of learning was labeled the “discovery learning” theory. Bruner believed in cognitive learning and that "massive transfer could be achieved by the appropriate management of learning.” 30 Akin to Reggio Emilia, Bruner supposed that organizing

\footnotetext{
${ }^{28}$ Jane K. Bates, Becoming an Art Teacher (Belmont, C.A.: Wadsworth/Thompson Learning, 2000), 282.

${ }^{29}$ Ibid., 7-8.

${ }^{30}$ John S. Brubacher, A History of the Problems of Education (New York, N.Y.: McGraw-Hill Book Company, 1966), 159.
} 
instruction so that children themselves would discover relationships rather than depend on the teacher to point them out. Bruner has divided the act of learning or creating into three steps: Acquisition of knowledge, Transformation of knowledge, and Evaluation of knowledge. Perceptual awareness involves absorbing knowledge; indispensable in the act of learning or creating. It is transformation that occurs during "free play" whereby the sensory knowledge (feeling or perceiving) is assimilated during the unstructured awareness stage into visual images. Evaluation of what was learned becomes critical in Bruner's model because without it, the inner demands of the individual remain diffuse and his self-motivation will not impel him or her to deeper levels of knowledge and involvement. ${ }^{31}$ Success in discovery then becomes self-rewarding.

"We do not learn a way of life and ways of deploying mind unassisted, unscaffolded, naked before the world. Rather it is through the give and take of talk, the active discourse with other minds, that we come to know about the world and about ourselves." $^{32}$

-Jerome Bruner, 1996

Bruner's method of learning is far from the roots of D.B.A.E. and the Eisner way of teaching and learning. Bruner is one of the contemporary educational philosophers whom the Reggio Emilia educators refer to when challenging the questions of: What is life? What is teaching? What does teaching mean? As described by Bruner in the above quote, teaching is a transformation of self that happens in a community that embraces and

\footnotetext{
${ }^{31}$ Donald Herberholz, and Kay Alexander, Developing Artistic and Perceptual Awareness: Art Practice in the Elementary Classroom (Dubuque, IA: William C. Brown Publishers, 1985), 16.

${ }^{32}$ Victoria R. Fu, Andrew J. Stremmel, and Lynn T. Hill, Teaching and Learning, Collaborative Exploration of the Reggio Emilia Approach (Upper Saddle River, N.J.: Merrill Prentice Hall, 2002), 202.
} 
lives on a notion of an education based on relationships. ${ }^{33}$ In Arthur Efland's book: Art and Cognition: Integrating the Visual Arts in the Curriculum, he refers to Vygotsky's belief in the role of play in development, stating that the play of children often portrays the roles they will carry out as adults. Because they are only playing, they are free to risk doing things they are not yet confident to do in real life.

Nelson Goodman actually founded Project Zero in 1967, with which Howard Gardner is associated, as a Harvard University Graduate School of Education Research Associate. He directed Project Zero until 1971, engaging in basic research into education and the arts, while also producing a number of arts orientation programs in film, dance, music, theater, and poetry. Goodman's philosophical studies ranged over many areas including logic, epistemology, and aesthetics.

It was Bruner who advanced the view of perception as an active process instigated by the learner. Vygotsky and Goodman advanced the notion of the importance of play, like Froebel, by stating "in play, children learn to understand the meaning of the world as they play with their representations of the world. They build concepts of mathematics and science as well as language, including literacy.”34

Edmund Burke Feldman is a contemporary art educator who has significantly influenced a procedure for dealing with art criticism in the classroom. In his publications Varieties of Visual Experiences (1992) and Becoming Human Through Art, which was written primarily for elementary classroom teachers, he presents these procedures:

\footnotetext{
${ }^{33}$ Victoria R. Fu, Andrew J. Stremmel, and Lynn T. Hill, Teaching and Learning, Collaborative Exploration of the Reggio Emilia Approach (Upper Saddle River, N.J.: Merrill Prentice Hall, 2002), 202.

${ }^{34}$ Arthur D. Efland, Art and Cognition: Integrating the Visual Arts in the Curriculum (New York, N.Y.: Teachers College Press, 2002), 124.
} 
-Description: Viewing a work of art and taking a visual inventory of its parts, noting what is immediately visible (objects comprising the subject matter and/or art elements used within the composition).

-Analysis: Discovering the relationships among the parts by attending to design principles within the composition.

-Interpretation: Discovering meaning within the work by focusing on the content and expressive qualities.

-Judgment: Evaluating quality by assessing the work on specific criteria and ranking it within the context of like works. ${ }^{35}$

These procedures are outlines by Feldman for the purpose of encouraging students to look at a work of art long enough to really see, to keep students from making immediate judgments, and to allow for powerful aesthetic experiences as viewers of art. ${ }^{36}$ Although it seems as if Feldman is referring to a beyond pre-school level of students, this concept of teaching can be employed at all levels of learning.

Feldman urges the professional educator to, “...think of yourself first as an art professional; your self-esteem ought to depend on your authenticity as an art professional; and your teaching should reflect the fact that art is your primary discipline.”37 Feldman stresses the commitment and responsibility educators have to inform administrators, faculty, and parents instructing: 1) follow a curriculum, 2) plan units of study, 3) teach content, 4) assess growth similarly as teachers in any other discipline do. He strongly believes in interdisciplinary education as an approach to organizing content and delivering instruction to students. If used properly, art can promote connections, meaning, and knowledge through all learning environments. Feldman believes we must be mindful in one’s approach, and suggests guidelines on how

\footnotetext{
${ }^{35}$ Jane K. Bates, Becoming an Art Teacher (Belmont, C.A.: Wadsworth/Thompson Learning, 2000), 209.

${ }^{36}$ Ibid.

${ }^{37}$ Ibid.
} 
to achieve this balance. Feldman also believes in “Art in the Mainstream,” accentuating the wider value of art education. He believes that art education is essential in developing positive attitudes toward work, enhancing literacy, and increasing understanding of human values. Feldman also believes in the arts as a catalyst, and that the visual arts are a language which can be used to teach students to read and use in their daily lives. Feldman's procedure based on his ideas about what professional critics do and his “subject-centered” prescriptive procedure for learning leaves little for discovery-based activity and is in no way child-centered.

In conclusion, Reggio Emilia is neither a model nor a program. It is an approach to teaching and learning and it is a way of thinking about these as well as the child, a way of life that promotes teaching as an art. The ideas of John Dewey, Lev Vygotsky, Howard Gardner, Jerome Bruner and many others penetrate the principles and practices found in the schools of Reggio Emilia. The Reggio Emilia approach reflects the concept of social constructivism, promotes listening to multiple voices, observing and recognizing different ways of knowing, seeing and making sense of things that are learned. The "coconstruction” of meaning and practice through inquiry, reflection, interpretation, and learning in the company of others is totally encouraged. This system of collaboration whereby a community (children, parents, and teachers) is working together to support the educational value of children's learning is crucial to the learning experience. This is the Reggio Emilia approach. 


\section{The Relationship Between Published Art Education Standards and Reggio Emilia: National and State (NAEA) Standards in Art Education}

Recently, the National Art Education Association published a new volume entitled Handbook of Research and Policy in Art Education, edited by Elliot Eisner of Stanford University and Michael Day of Brigham Young University and copyrighted in 2004. This volume is a comprehensive guide to the history of art education, policy perspectives, learning in the visual arts, teacher education, forms of assessment in art education, and emerging visions in the field of art education. In the introduction, the editors state their goal of bringing together research and theory, policy and concepts as to what current art educators are trying to achieve. Eisner and Day remark that to date there is a "healthy diversity" of opinion as to the aims and the content of art education practices. Educational philosophers and educators including Matthews, Katz, Vygotsky, and as far back as Froebel all agree with the Reggio Emilia theories such as learning in groups, collaboration, documenting the process as you go, etc. In other words, all of the basic principles of Reggio Emilia are being revisited as attention switches from a subjectcentered curriculum to a child-centered curriculum.

According to the new Handbook of Research and Policy in Art Education, recent developments profess that the theory of “a learner-centered and developmental curriculum»38 are particularly observed in early childhood education. Including a series of chapters contributed to by worldwide art educators, this handbook is the most current publication in art education research and policies. John Matthews of the National Institute of Education in Singapore has contributed a chapter entitled “The Art of Infancy.” In this chapter, Matthews carefully observes preschool children drawing with the computer in a

\footnotetext{
${ }^{38}$ Elliot Eisner and Michael Day, Handbook of Research and Policy in Art Education (Reston, V.A.: National Art Education Association, 2004), 282.
} 
London-based childcare center as well as children in Singapore drawing with conventional materials such as pencil and paper in a similar setting. The children are told they can draw whatever they like. What is so invigorating is that some of the children have never drawn before, yet they start off drawing with great enthusiasm. Matthews observes that they appear to investigate the properties of the drawing medium by testing the pencil's abilities. Matthews analyzes the wide variety of marks, shapes, and movements, speeds at which this drawing process takes place. What is also so wonderful and refreshing are the examinations coming from the students about what they are drawing. There is a vast array of ideas as to what is being produced. The students vocalize objects that they see formed by the drawings, resonate sounds that relate to the object, and even lift the paper to show how the plane is flying and actually demonstrate the motion of the object through space. These descriptions are used by Matthews to demonstrate how crucial the role of art is in development and learning. He extends this to the role of all of the arts, both visual and performing arts. Matthews believes that “...making marks on two-dimensional surfaces...is going to remain central to the way human beings think and live." ${ }^{39}$ He also trusts that the analysis of these drawing exercises takes us "straight to the heart of fundamental issues in art, education, representation, and human development.” Matthews also believes that the interpretations of these kinds of activities are the beginnings of visual expression and representation, and therefore become essential to art educators worldwide. John Matthew’s thinking is unquestionably parallel to the basic principles of the Reggio Emilia approach.

\footnotetext{
${ }^{39}$ Elliot Eisner, W. and Michael Day, Handbook of Research and Policy in Art Education (Reston, V.A.: National Art Education Association, 2004), 282.
} 
In the subject-orientated curriculum, the transmission of "knowledge" is assumed to automatically confer intelligence to the student. In this chapter, John Matthews states that the research that has been done concludes that there is no scientific evidence that supports this assumption. By contrast, it verifies that developmental curricula and early mediation between a caregiver and infant "produces sustained gains in intelligence, caring, sharing and happiness.” 40 The processes of human development are what the developmental curricula are based on. It has been said that early childhood education is considered an approach to learning that is "not tied to the transmission of any particular culture or body of knowledge.” The available subject area in art is significant “only insofar as it contains process, instruments, and experiences” which are directed at stimulating and promoting human developmental emphasis. Interestingly enough, one of many of the researchers listed supporting the aforementioned theory is Lilian Katz, a Reggio Emilia authority. Lilian Katz’s many publications include Reflections on the

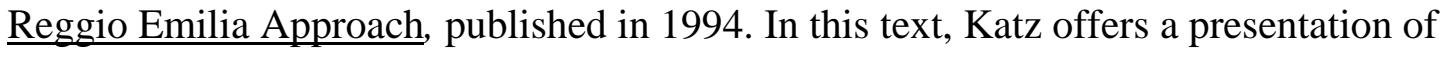
papers by various authors expressing the trend toward integrating the curriculum, and the impressive reports of group projects conducted by children in the pre-primary schools of Reggio Emilia. These researchers have reevaluated the ecological and developmental niche of early childhood curriculums and believe that the learning experiences developed in accordance with this philosophy nourish "unfolding development spontaneously generated from the child. Specifically, it is Lilian Katz who in 1992 inquired about what young children should be learning rather than what they are capable of learning in “contrived” situations.

\footnotetext{
${ }^{40}$ Elliot W. Eisner, and Michael Day, Handbook of Research and Policy in Art Education (Reston, V.A.: National Art Education Association, 2004), 283.
} 
Incidentally, a recently renewed interest in the work of Vygotsky has brought about a concern for the child's personal and individual development and the social and interpersonal aspects of learning. The caring and emotional side of education is a new trend in educational psychology. It is the promoting of human development that becomes more of a regime in childcare and educational environments. In favor of the transmission of information, the curriculum for the very young is not to be viewed as a "watered-down version of product-oriented, subject-driven teaching, but has to acknowledge processes of human development." 41

John Matthews warns that this new concept of developmental theory will not be embraced quickly or on a wide scale. He professes it will take a while for this theory to sink in. As there is governmental involvement in curriculum planning, theories have a tendency to go from mere descriptions to step-by-step requirements of the students or in other words become subject-centered. Matthews also states that for the sake of making subject-driven, exam-oriented teaching palatable to younger children, a typical curriculum developed for the older child and adolescent is diluted down to its simplified form for younger students. According to Lilian Katz, this has the profound effect of “damaging the disposition to learn" 42 in early childhood. It is the Reggio Emilia philosophy that through the discovery process the subject is to be shaped by the child. John Matthews proclaims that the fear of this kind of quick-fix thinking will produce a series of shallow cognitive skills, word recognition, and recitation, which has little to do with discovery learning.

\footnotetext{
${ }^{41}$ Elliot W. Eisner and Michael Day, Handbook of Research and Policy in Art Education (Reston, V.A.: National Art Education Association, 2004), 670.

${ }^{42}$ Ibid, 283.
} 
In this same chapter of the Handbook of Research and Policy in Art Education, John Matthews proclaims “there is an important relationship between play and children’s use of art media because it is within play that the child discovers and exercises skills in symbolization, representation, and expression; skills that are carried over-or 'transported' -to visual and other media. Play is crucial for the child's understanding and use of symbols, signs and representations...” In terms of Vygotsky's philosophy, play allows the child to separate words from objects, actions from meanings, which has essential consequences for learning. As noted additionally by Bruner, when objects and action are set free from their constraints in adaptation to reality, flexibility is allowed to occur.

This new publication seems to be reflecting an interest in child-centered learning and illustrates the differences in philosophies that affect policy as it pertains to subjectcentered vs. child-centered learning. However developmental research and theory does support much of the Reggio Emilia approach.

The National Standards for Arts Education are a statement of "what every young American should know and be able to do” in the four arts disciplines: Dance, Music, Theatre, and Visual Arts, specifically derived for the K-12 age group. Upon careful perusal of the current National Standards for Arts Education (found on the web at: http://wvde.state.wv.us/policies/p2520.12.doc and is also available for viewing in the Addendum following this paper), it is interesting to observe the specific goals and how they compare/contrast to the Reggio Emilia principles we have discussed. Under the heading What Students Should Know and Be Able to Do in the Arts, students are urged to work in all of the arts. Competence is defined to mean the ability to use an array of knowledge and skills. A student's abilities will range widely and develop at a 
variety of rates. The work will build upon continual knowledge obtained (content), effort put forth, and in conclusion, the "joy of experiencing the arts is enriched and matured by the discipline of learning and the pride of accomplishment” ${ }^{43}$ (achievement). By the time the student has completed secondary school, they are expected to know and be able to: communicate at a basic level the four arts disciplines—dance, music, theatre, and the visual arts; communicate proficiently in one of the arts forms; develop and present basic analysis of works of art; have an informed acquaintance with exemplary works of art from a variety of cultures and historical periods; and they should be able to relate various types of arts knowledge and skills within and across the arts disciplines. According to the authors of the Standards, the result ends in the students being able to arrive at their own knowledge, beliefs, and values for making personal and artistic decisions.

In the 1980s, an educational reform was generated, which resulted in the Standards being developed. In 1990 several national educational goals were announced, based on the 1983 publication A Nation at Risk which served as a national wake-up call, strongly affecting the climate of the arts and the education of these arts. There is currently a new reform to describe the "knowledge and skills students must have in all subjects to fulfill their personal potential., 44

As stated by Elliot Eisner and Michael Day the importance of these developed standards are two-fold. First, they define what a good education in the arts should provide: a thorough grounding in a basic body of knowledge (i.e.: subject-centered) and the skills required both to make sense and make use of the arts disciplines. Second, when adopted these Standards they are "taking a stand for rigor in a part of education that has

\footnotetext{
${ }^{43}$ http://wvde.state.wv.us/policies/p2520.12.doc

${ }^{44}$ Elliot W. Eisner and Michael Day, Handbook of Research and Policy in Art Education (Reston, V.A.: National Art Education Association, 2004), 283.
} 
too often, and wrongly been treated as optional." ${ }^{45}$ In essence, this document professes that an education in the arts should reach the obtainable goals as spelled out and reaches clear levels of attainment at their specific grade levels. It is clear that these standards are in sharp contrast to the Reggio Emilia viewpoint that through discovery the subject is shaped by the child, thus rendering the curriculum subject-centered.

The next segment to review is the state standards, formally known as: Visual Art Content Standards and Objectives for West Virginia Schools. A one hundred page document describing the objectives for Kindergarten through $12^{\text {th }}$ grades, this $2003-2004$ version, also referred to as Policy 2520.12 can be found on the web at: http://wvde.state.wv.us/policies/p2520.12.doc. This document details the achieved curriculum refinement assessed by statewide educators in the field of art. Based on the most current research by the board of educators writing these standards, national standards and best teaching practices in the field, this document presents content and curriculum that are sequential teaching goals for West Virginia Art Educators. Issues of utmost importance are stated as: "building a rigorous and challenging curriculum, ensuring a curriculum that is accessible to every student, and designing a format that can easily be used and understood." 46 Specifically, the content area begins with a set of content standards, with grade-level objectives organized under the standards, to keep the focus on helping students achieve the comprehensive goals, and not just mastering the incremental steps. Although the objectives remain intact, and were created ostensibly for the visual arts as of 2003, we do not necessarily see any reminiscence of a Reggio Emilia type of approach. In other words, this policy deeply concerns itself with assessment and

\footnotetext{
${ }^{45}$ Elliot W. Eisner and Michael Day, Handbook of Research and Policy in Art Education (Reston, V.A.: National Art Education Association, 2004), 283.

${ }^{46}$ http://wvde.state.wv.us/policies/p2520.12.doc
} 
accountability, instructional goals and objectives, yet does not actually mention the

student's abilities to learn, taking into account their background, their capacity to learn or their gift to take presented information and be creative with it in their own individual way. The Summary of the Content Standards and Objectives reads:

The West Virginia Board of Education has the responsibility for establishing high quality standards pertaining to all educational standards pertaining to all education programs (W.Va. Code §18-9A-22). The content standards and objectives provide a focus for teachers to teach and students to learn those skills and competencies essential for future success in the workplace and further education. The document include content standards for $\mathrm{K}-12$ visual art, an explanation of terms; objectives that reflect a rigorous and challenging curriculum; and performance descriptors.

This indeed is not in compliance with the Reggio Emilia philosophy.

\section{The Relationship Between Reggio Emilia and Art Education Standards and Practices: Two Examples, Chapman and Hubbard}

Both Laura Chapman and Guy Hubbard are contemporary professors in the field of art education. Laura Chapman is a currently practicing art educator who has written the widely used textbooks for use in public elementary schools entitled Discover Art and a more recent Adventures in Art series from the eighties. Additionally, there is a student reference book that accompanies the text. It is touted as a wonderful resource to many art educators. ${ }^{47}$ The Laura Chapman resources offer a variety of educational resources and tools including transparencies, posters, art reproductions, and assessment masters. The purpose of these materials is to aid art educators and classroom teachers in the creation of

\footnotetext{
${ }^{47}$ http://www.getty.edu/artsednet/hm/Mar01/0520.html
} 
lesson plans and an art curricula. ${ }^{48}$ Like Chapman, Guy Hubbard has also developed a method of teaching art education as seen in his text Arts and Activities, from the late seventies, complete with student workbooks and teachers guides. Hubbard has wonderful ideas about collecting and retrieving picture archives to help in teaching art and other subjects. Because of the continued sale of their textbooks, both of these art educators are well-known authors of art curriculums in public school programs. They give formula oriented projects, all in a similar and easy to follow format. This subject-centered, formula approach to learning is far from the Reggio Emilia approach.

It is clear that neither of these educators directly relate to the Reggio Emilia approach with respect to the basic philosophy as outlined previously. In most cases, philosophy can set the policy of what and how education is being taught and learned. The thinking represented in Chapman and Hubbard concerns itself less with the romantic notions or idealism of teaching (like Froebel and Rousseau's concepts of learning) and deals more with using the subject itself as forming the basis for teaching and learning.

In the teacher's edition, Laura Chapman series Level 5 ( $5^{\text {th }}$ Grade) for instance, one can denote the differences between a Reggio Emilia approach vs. a Chapman approach. The welcome section claims this to be a "proven classroom tool for inspiring students to perceive, create, and appreciate the visual arts...a comprehensive curriculum that interweaves art appreciation, history, criticism, and production." ${ }^{49}$ It welcomes you to "art explorations that encourage critical and creative thinking while building an awareness of art in everyday life.... rich visual environment in which students create,

\footnotetext{
${ }^{48}$ http://www.libraries.uc.edu/libraries/daap/cmp/subjectguides/art/arteducation.html

${ }^{49}$ Laura H. Chapman, Discover Art Series (Worcester, M.A.: Davis Publications, Inc., 1985), 2.
} 
read, write, listen, talk and learn about art," ${ }^{50}$ and asserts that this is the "leading program for creating meaningful learning experiences, and fostering a lifelong interest in art.”51 The format of this series contains a student textbook, a big book- for ease of instruction in group settings (including large-sized versions of the student textbooks) in a bound, self-standing easel, a teacher's wraparound edition complete with a three step teaching sequence applied to all sixty lessons in an easy-to-follow format including pointers for cooperative learning, interdisciplinary learning, and individual needs learning. Unit openers precede the units providing a quick overview to get you started and assist you in tailoring the program to your specific curriculum needs. There are cd-roms with interactive enrichment ideas, large reproductions of art images, reproducible assessment masters- allowing the teacher to measure progress throughout the program, slide sets, overhead transparencies, etc. It is presented as a complete package of how to teach art, particularly in a public school setting.

“Art is one of many important ways for children and young people to express what they see, know, feel, and imagine. Art is also a subject for study; a legacy of visual images from around the world, past and present. Adventures in Art provides a foundation for students to develop a lifelong interest in art”52 proclaims the developer, Laura Chapman.

In the Guy Hubbard series Art in Action and the series entitled Art: Meaning, Method, and Media, we observe prescribed units and lesson plans created by this art educator. In the text Art in Action, we see units presented such as: "Seeing Like an Artist”, “Exploring with the Tools of Art”, “Art Then and Now”, and “Art Enriches Our

\footnotetext{
${ }^{50}$ Laura H. Chapman, Discover Art Series (Worcester, M.A.: Davis Publications, Inc., 1985), 2.

${ }^{51}$ Ibid.

${ }^{52}$ Ibid.
} 
Environment”. Hubbard includes a comprehensive glossary and “Artist's Reference” to accompany this textbook. The "Artist’s Reference” simply refers back to the works by famous artists presented in the textbook. This reference encourages the teacher and the student to use this list to locate particular paintings, drawings, sculptures, and other artworks and to "find works by other artists who especially interest you" ${ }^{\text {"53 }}$. In his Art: Meaning, Method, and Media series, we have a series of prearranged lesson plans (60 of them per textbook), whereby the teacher can simply read the directions laid out by Hubbard and follow them. For example, on a $5^{\text {th }}$ grade level, Lesson \#1 starts with the title "A Nice Thing That Happened to Me". This lesson proceeds to initiate thoughts with the question "What did you do over summertime?” We all know that is the first thing that a teacher asks when the students come back to school in the fall, no matter what age student they are teaching. It proceeds to jog the students mind about what activities they did over the summer by showing a photograph of Norman Rockwell's “The New Television Set”, commenting that perhaps you went on a special trip somewhere and had a new television set like in this picture. The exercise continues by asking the student to try and remember exactly what your experience was like. Then draw a picture of it. "The picture should fill all of your paper" ${ }^{34}$ commands Hubbard. It states that you should draw in pencil lines and color the picture with crayons until the white paper is all covered. "Press hard with your crayons in some parts and shade lightly in other parts." ${ }^{55}$ Hubbard states that the picture could be created on colored paper because "good pictures do not always have to be done on white paper." 56

\footnotetext{
${ }^{53}$ Guy Hubbard, Art In Action Series San Diego, C.A.: Coronado Publishers, 1987), 5.

${ }^{54}$ Ibid., 6.

${ }^{55}$ Ibid.

${ }^{56}$ Ibid.
} 
This type of thinking by both Chapman and Hubbard is completely contrary to the Reggio Emilia principles. Firstly, the image of the young child seemingly has no bearing on this method of learning art. By image of the child, consider the positive attitude Reggio Emilia subscribers hold for the child itself, and their inherent knowledge and competency with which they arrive to the classroom. Secondly, the nature of the learning process, is not taken into account by Chapman and Hubbard. By nature of the learning process, reflecting back on the first principle, the image of the child, to clearly understand that the learning process is one of collaboration. The ideas for projects are generated from the result of teacher-student interaction, in combination with a child's everyday experiences in life. This cooperative relationship then becomes the basis for the activity, not the subject chosen by a textbook written on how to teach art. Thirdly, the process of collaboration is not exercised by Chapman and Hubbard because there is little discoverybased learning. With the notion of collaboration being defined as constructing knowledge by working with others, be it peers, teachers, parents, or community members, this principle has no bearing in the Chapman or Hubbard methodology. Neither Chapman nor Hubbard design lesson plans for long-term usage, nor are they designed in an open-ended manner. Perhaps, their lesson plans are designed to be completed in one forty minute class period with the goal of making a piece of art. This absolutely negates the Reggio principle that creativity takes time. Granted the lack of longer, unstructured blocks of time, which are not available in a public elementary school environment, hinder the learning environment. As far as documentation is concerned, there is truly neither time nor effort made to conduct this enrichment procedure as part of the student's educational experience. Remember, it is the act of documentation that captures the "life" of the 
project. Which means documentation is defined as "any activity that renders a performance record with sufficient detail to help others understand the behavior recorded". ${ }^{57}$ Therefore, a videotape of the child creating the drawing would be considered documentation. The intent is to explain, not merely to display the depth of the students learning and the educational rationale of the activities. In other words, ongoing discussions of this documentation are the norm. The students watch themselves learning, they discover how to learn versus being told how to learn in a specific way.

Deep understanding, another guiding principle of Reggio Emilia, urges the students to consider exploration of ideas from many different points of view. This belief is not found in the conceptual thinking of both Chapman and Hubbard. Other Reggio Emilia principles previously described such as: unity of thinking and feeling, exploration, representation, communication do not exist in this fixed methodology. By combining thinking and feeling, the children's interests are considered and their emotions are paid attention to. This is one feature that distinctly defines child-centeredness. In Chapman and Hubbard's curriculums, the art is what is paid attention to. There is a slight hint of this connection between art and feelings with Hubbard for instance when he states in his "Learning Objectives" section in one of his teachers guides "Students will recognize the connection between feelings and art." ${ }^{58}$ Yet, there is very little time spent on the investigation of how studied examples of artwork reflect the students' environment, understanding, view of their own world, or the exploration of elements within their own life.

\footnotetext{
${ }^{57}$ Carolyn Edwards, Lella Gandini, and George Forman, The Hundred Languages of Children: The Reggio Emilia Approach - Advanced Reflections (Westport, C.T.: Ablex Publishing Corporation, 1998), 241.

${ }^{58}$ Guy Hubbard, Art In Action Series (San Diego, C.A.: Coronado Publishers, 1987), 6.
} 
Reggio principles such as questioning and adaptation, using an everyday experience to enhance a child's view of the world, provokes the child's natural instincts. There seems to be very little room for this in the lesson plans of Chapman and Hubbard, based on the formulaic mode of production of art rather than analysis of art and life. Another Reggio tenet, reflection or considering something carefully, is not apparent in the teaching methods of Chapman and Hubbard. With projects of such short duration and limited periods of time, the student is forced to cover as much "art stuff" versus "kids stuff" because of this imposed time constraint and the "subject" mattered elements. It is the founder of Reggio Emilia, Loris Malaguzzi (died in 1994), whose belief is that the children who are the best evaluators, and the most sensitive judges of the values and usefulness of creativity. He believes that because they are not attached to their own ideas, they are able to continuously construct and reinvent their ideas. Malaguzzi further states that children are "apt to explore, make discoveries, change their points of view, and fall in love with forms and meanings that transform themselves." ${ }^{59}$ This is again considered "natural” given the point of view about the nature of the child. Finally, the concept of research - to observe and to brainstorm, adheres to the aforementioned statement. It is Malaguzzi's philosophy on creativity that brilliantly expresses the current trends in this form of progressive education. In summary, Malaguzzi believes that creativity is our way of thinking, knowing, and making choices. It stems from multiple experiences, supported by personal resources including a sense of freedom to venture beyond the known. Unexpected solutions are arrived at through cognitive, affective, and imaginative processes. Creativity is best expressed through interpersonal exchange. According to

\footnotetext{
${ }^{59}$ Carolyn Edwards, Lella Gandini, and George Forman, The Hundred Languages of Children: The Reggio Emilia Approach - Advanced Reflections (Westport, C.T.: Ablex Publishing Corporation, 1998), 75.
} 
Malaguzzi, creativity finds its highest power when adults are "less tied to prescriptive teaching methods, but instead become observers and interpreters of problematic solutions. ${ }^{60}$ This statement about creativity alone is the decisive difference between the Reggio Emilia approach and the Chapman or Hubbard methods. Malaguzzi also believes that the expectations of teachers, schools, families and communities allocate whether to favor or disfavor creativity based upon the ways children perceive those expectations. Chapman and Hubbard do not take into account the child's perspective, or their creative capacity in terms of imagination, fantasy, intellectual and expressive activities, which both multiply and unify the ultimately creative mind. The Reggio Emilia philosophy states that creativity requires that the school of knowing finds connections with the school of expressing, opening the doors to the hundred languages of children. Therefore, the Chapman and Hubbard methods do not truly support the Reggio Emilia approach.

\section{Can Art Education Be Taught in a "Reggio Emilia” Way in the U.S. Public Schools?}

Given the principles of Reggio Emilia described here, the question then becomes:

How would an art teacher have to adjust his or her curriculum in order to create a Reggio Emilia environment for learning? The following addresses this issue.

The art education standards and policies and examples examined in this paper present the art curriculum as essentially subject centered. In direct contrast to this is Reggio Emilia’s child-centered approach. The question is: could this change to a Reggio

\footnotetext{
${ }^{60}$ Carolyn Edwards, Lella Gandini, and George Forman, The Hundred Languages of Children: The Reggio Emilia Approach - Advanced Reflections (Westport, C.T.: Ablex Publishing Corporation, 1998), 75.
} 
Emilia approach be made simply by adapting a Chapman or a Hubbard lesson or adjusting various published standards?

The answer to this question lies in the reexamination of the basic guiding principles of Reggio Emilia. In discovery-based learning, aspects of the subject of art are given a chance to naturally emerge. In subject-centered learning, given the Chapman and Hubbard curricula and the national and state standards, coverage and sequence are the driving force.

As previously discussed, in the first Reggio Emilia principle: the nature of the learning process...environment is everything. The learning process is collaborative and discovery-based, taking the form of long-term projects designed in an open-ended manner. Documentation occurs when teachers record by various methods what the students discover, throughout the process of this discovery. Deep understanding is the result of all of the above.

Principle two is the concept of: unity of thinking and feeling. This is categorized by: exploration, representation, and communication. By exploration, the suggestion is to bring to life the environment the children reside in. Representation is the way in which children record and embody their memories, ideas, predictions, hypothesis, observations, and feelings. Communication is about the student's ability to express their own thoughts and ideas, and allowing them to do so. This principle is inextricably linked to the childcentered, discovery based curriculum.

The third principle deals with the value given to questioning and adaptation, reflection, and research. These elements exist in the context of a project that the child has, to a large extent, shaped and defined. Of course, by themselves they are not special or are 
non-existent in a subject-centered curriculum, but in the context of the Reggio Emilia child centered curriculum they gather their significance.

Again, many of these principles in isolation could be operating in a context other than a Reggio Emilia one. However, the Reggio Emilia philosophy of the nature of the child and the nature of the learning process is contrary to a subject-centered curriculum. This makes it illogical to propose that subject-centered curricula could be adapted to the Reggio Emilia philosophy and approach. It would require that art education practices (as outlined in this paper) become child-centered to the degree that these subject centered practices be abandoned.

This conclusion was somewhat confirmed as a result of an in depth tour of the Reggio Emilia schools in Reggio Emilia, Italy, from May 27, 2005 through June 4, 2005. In visiting the schools, much more could be realized by seeing the authentic environment and listening to the pedigogistas describe in detail their teaching philosophy. The goal of the Reggio Emilia staff is to create a context where we learn how to learn. In other words, the learning that occurs in this type of school is open-ended and continually questioned and open to changes that occur when learning is child-centered and discovery based. Their belief is that learning is a combination of elements: teacher, learner, and researcher collaborating together deeply, strongly, and with valiant effort. I witnessed a weaving together of theory and practice. The Reggio Emilia method places much value on the action of thinking. Connections are realized and bridges are built. The teachers believe that children are our best evaluators. Children need freedom to think and to try new things. This is part of the discovery-based philosophy as is known to Reggio Emilia. Emphasis is placed on observing and respecting the children's rhythm. How they think, 
move, work individually and together, how they use their creativity in their daily routine is all taken into account. The children establish their own rhythm. That rhythm comes from within the children. It is not imposed on them via schedules and standards. At Reggio Emilia, responsive rather than directive learning and teaching were observed on location. Essentially the activities observed at the schools were consistant with the Reggio Emilia principles. The children, the faculty and the parents worked in collaboration which was evident by the extent to which the adults allowed this "rhythm" to emerge from the children.

\section{Implications for Art Education}

Prospects for incorporating the Reggio Emilia philosophy into the art curriculum in America are unlikely as curriculum standards go today. This would be so for two reasons. Firstly, the current view of the student, and secondly the view of the subject. With the current view of the student being oriented to test taking and having to follow proposed guidelines mandated by national and state standards, there is little room for envisioning the application of the Reggio Emilia method. Secondly, the current view of the subject that consists of concepts and skills integral to the discipline and experience in developmental sequence renders a child centered, discovery based approach unlikely.

Although, prospects for applying this method at the high school level may seem promising, especially for high schools on a block schedule (with 90-minute periods x 4 per day vs. 40-minute x 8 periods a day) which would allow more time in a given day to explore an open-ended curriculum. However, the essential principles of Reggio Emilia 
would require that the curriculum be redesigned from a subject centered one to one that is student centered. Therefore the extra time that would exist is not the issue.

To incorporate Reggio Emilia in our current Art Education structure would require re-thinking ideas about art, teaching art, and the child/student which would involve doing so in the light of current developmental theory. As a result of this project, it is clear that the Reggio Emilia approach to education, while it has many attractive individual features, requires that all of the guiding principles be implemented.

The Reggio Emilia approach, a philosophy of teaching and learning and personal development creates conditions where learning about the subject of art is an incidental outcome of this philosophy. 


\section{REFERENCES:}

Barnet, Sylvan. A Short Guide To Writing About Art. New York, N.Y.: Longman, 2003.

Bates, Jane K. Becoming an Art Teacher. Belmont, C.A.: Wadsworth/Thompson Learning, 2000.

Brubacher, John S. A History of the Problems of Education. New York, N.Y.: McGrawHill Book Company, 1966.

Cone, John D. and Foster, Sharon L. Dissertations and Theses from Start to Finish; Psychology and Related Fields. Washington, D.C.: American Psychology Association, 1995.

Cornett, Claudia E. Creating Meaning Through Literature and the Arts: An Integration Resource for Classroom Teachers. Upper Saddle River, N.J.: Merrill Prentice Hall, 2003.

Chapman, Laura H. Discover Art Series. Worchester, M.A.: Davis Publications, Inc., 1985.

Dobbs, Stephen Mark. Research Readings for Discipline-Based Art Education: A Journey Beyond Creating. Reston, V.A.: National Art Education Association, 1988.

Edwards, Carolyn, Gandini, Lella, and Forman, George. The Hundred Languages of Children: The Reggio Emilia Approach - Advanced Reflections. Westport, C.T. Ablex Publishing Corporation, 1998.

Efland, Arthur D. Art and Cognition: Integrating the Visual Arts in the Curriculum. New York, N.Y.: Teachers College Press, 2002.

Eisner, Elliot W. and Day, Michael. Handbook of Research and Policy in Art Education. Reston, V.A.: National Art Education Association, 2004.

Eisner, Elliot W. The Role of Discipline-Based Art Education in America's Schools. Los Angeles, C.A.: The Getty Center for Education in the Arts.

Fu, Victoria R., Stremmel, Andrew J., and Hill, Lynn T. Teaching and Learning, Collaborative Exploration of the Reggio Emilia Approach. Upper Saddle River, N.J.: Merrill Prentice Hall, 2002.

Herberholz, Donald and Alexander, Kay. Developing Artistic and Perceptual Awareness: Art Practice in the Elementary Classroom. Dubuque, IA: William C. Brown Publishers, 1985. 
Hubbard, Guy. Art In Action Series. San Diego, C.A.: Coronado Publishers, 1987.

Hudson, Suzanne and Noonan-Morrissey, Nancy. The Art of Writing About Art. Belmont, C.A.: Wadsworth Group/Thompson Learning, 2002.

Katz, Lilian and Cesarone, Bernard. Reflections on the Reggio Emilia Approach. Urbana, I.L.: ERIC Clearinghouse on Elementary and Early Childhood Education, 1994.

Langer, Suzanne. Problems of Art: Ten Philosophical Lectures. New York, N.Y.: Charles Scribner and Sons, 1957.

Snowman, Jack and Biehler, Robert. Psychology Applied to Teaching. Boston, MA: Houghton Mifflin Company, 2000.

Strayer, George Drayton and Norsworthy, Naomi. How To Teach. New York, N.Y.: The Macmillan Company, 1921.

"Loris Malaguzzi, Founder: The Reggio Emilia Approach, Believing in the Power of the Child.” Scholastic Early Childhood Today. (May/June 2001): 46.

Tarr, Patricia. "Aesthetic Codes in Early Childhood Classrooms: What Art Educators Can Learn from Reggio Emilia”. Art Education. (May 2001): 33-39.

Gandini, Lella. “Scholastic Pre-K Today”. (October 1992): 81-84.

Gude, Olivia. "Postmodern Principles: A 21 ${ }^{\text {st }}$ Century Art Education”. Art Education. (January 2004): 6-13.

Breig-Allen, Cheryl, Hill, Janet, Geismar-Ryan, Lori, and Cadwell, Louise Boyd. "The Language of Lines”. Young Children. (July 1998): 64-66.

Gardner, H. Complimentary Perspectives on Reggio Emilia,1993 (see pg. 80 of Katz, Lilian and Cesarone, Bernard. Reflections on the Reggio Emilia Approach. Urbana, I.L.: ERIC Clearinghouse on Elementary and Early Childhood Education, 1994.)

Walls, Richard T. Psychological Foundations of Learning. Morgantown, W.V.: West Virginia University, 1999.

Spaggiari, Sergio and Rinaldi, Carla. The Hundred Languages of Children: Catalog of the Exhibit. Reggio Emilia, Italy: Reggio Children, 1996. 


\section{VIDEOS:}

Forman, George and Gandini, Lella. "An Amusement Park for Birds: A Long Term Project Completed at La Villetta School in Reggio Emilia Italy”. Amhurst, M.A.:

Performanetics, 1994

The Long Jump: A video analyses of small group projects in early education practice in Reggio Emilia, Italy, (1991) Forman G.E.\& Gandini L. A long term project at the Diana School in Reggio Emilia. (Available from Performanetics, 19 The Hollow, Amherst, MA 01002)

The Creative Spirit, (PBS 1992). Segment on Reggio Emilia in (Creative Beginnings). PBS Video, 4401

An Amusement Park for Birds, (1994) Forman G.E. \& Gandini, L. A long term project at La Villetta School in Reggio Emilia. (Available from Performanetics, 1994 The Hollow, Amherst, MA 01002). 